\title{
CYCLIC NUCLEOTIDES, PROSTAGLANDINS AND POLYAMINES IN PSORIASIS
}

\author{
Cynthia L. Marcelo and John J. Voorhees \\ University of Michigan Medical School, Department of Dermatology, \\ Kresge Research Building I, R-6558 Ann Arbor, Michigan 48109, US A
}

\section{INTRODUCTION}

Psoriasis is a complex, probably hereditary proliferative skin disease. Numerous studies done over the last years demonstrate an imbalance of a variety of intracellular mediators and related biochemical systems in the diseased skin, and it is probable that the interplay of these modulators may determine the final expression of the disease in the epidermal component of the tissue. Our aim is to review the state of these systems in psoriasis, to report the functions that these modulators can effect in the epidermis, and to discuss how the interplay of these systems may be involved in the modulation of epidermal cell homeostasis.

\section{PSORIASIS}

As suggested by Watson et al. (1971) and Farber et al. (1974) multifactorial heredity and the environment may be important determinants in the cutaneous expression of psoriasis. Individuals with this disease have increased frequencies of specific cell-surface products of the HLA antigen groups (Woodrow et al., 1975, and Beckman et al., 1977), develop the disease either spontaneously or in an area of skin damage, and show seemingly partially uncontrolled, nonmalignant growth of the epidermis. The involved epidermis is characterized by markedly increased proliferative rates (Weinstein and McCullough, 1973; Marks, 1978; Harper et al., 1978), reduced epidermal cell differentiation (Voorhees et al., 1974; Voorhees et al., 1968) and an increased glycogen content (Voorhees et al., 1974). The epidermal abnormality is not restricted to the lesional area since the normal appearing skin of the psoriatic patient has been reported to show a 48 per cent increase in DNA synthesis when compared to normal human skin (Marks, 1978).

The cause of the misregulated epidermal cell growth in psoriasis is unknown. Numerous investigations of psoriatic epidermis have pointed to the involvement of several mediators and their biochemical regulatory systems, possibly as critical or primary modulators, in epidermal cell regulation. These are the cyclic nucleotide, the arachidonic acid and prostaglandin, and diamine and polyamine systems.

\section{THE CYCLIC NUCLEOTIDE SYSTEM}

\subsection{CYCLIC AMP}

\subsubsection{Metabolism}

Cyclic AMP (adenosine 3',5'-monophosphate) is predominantly located in the cytoplasm of the basal cells of the epidermis (Verma et al., 1976). In the skin, as in other tissues, the level of cyclic AMP is regulated by its rate of formation and degradation. The formation of cyclic AMP from ATP is catalyzed by the cell membrane bound enzyme adenylate cyclase (Duell et al., 1971; Marks and Rebien, 1972a). Cyclic AMP is degra- 
dated by hydrolysis to 5' AMP. Cyclic nucleotide phosphodiesterase(s) catalyze this reaction and may be present in multiple forms in the skin (Voorhees et al., 1973; Marks and Raab, 1974; Rusin et al., 1978; Murray and Rogers, 1978).

At present, all the effects of cyclic AMP on cell organ function are thought to be mediated by specific activation by cyclic AMP of protein kinase (see Corbin and Lincoln, 1978 for a complete discussion) which catalyzes the phosphorylation of a variety of protein acceptors by ATP (Kumar et al., 1971; Voorhees et al., 1972a). Cyclic AMPdependent protein kinase exists as a dimer of associated regulatory $(\mathrm{R})$ plus catalytic $(\mathrm{C})$ subunits, i.e., $(\mathrm{RC})_{2}$. The regulatory subunit inhibits the enzymatic activity of the catalytic unit by binding to it. This inhibition of $\mathrm{C}$ by $\mathrm{R}$ is relieved by the binding of cyclic AMP to $R$ and the subsequent dissociation of the $R$ and $C$ units. The free catalytic unit then phosphorylates various protein substrates resulting in the biological effect of cyclic AMP (see George and Ignarro, 1978 for a review of other tissues). Cyclic AMP-dependent protein kinase has been demonstrated to exist in multiple forms in monkey (Kumar et al., 1973), adult and neonatal skin (Kumar et al., 1972; Kumar et al., 1976). The biological significance of these various forms in the skin is at present unknown although interaction of the cyclic AMP and polyamine systems in other tissues has been suggested to occur through activation and inhibition of specific types of protein kinase (Bachrach et al., 1978; Byus et al., 1978; Hochman et al., 1978).

\subsubsection{Assay}

The epidermis contains approximately $0.2-0.4 \mathrm{pmol}$ of cyclic AMP/ $\mu \mathrm{g}$ DNA (see Table 1) and therefore no more than $16-20 \mathrm{pmol}$ of cyclic AMP are present in the average epidermal biopsy obtained from a psoriatic or normal person. Two sensitive and specific radio-ligand assays have been used to measure cyclic AMP in the epidermis. One method is the protein binding assay reported by Gilman (1970) which utilizes rabbit muscle protein kinase. The competition of ${ }^{3} \mathrm{H}$-labeled cyclic AMP and unlabeled cyclic AMP in standards and samples for the R unit of the enzyme complex forms the basis of the assay. The second assay is a radioimmunoassay which involves competition of labeled $\left({ }^{125} \mathrm{I}\right)$ and unlabeled cyclic AMP for highly specific antibody (Steiner et al., 1969). When studying epidermal tissue, it is necessary to remove interfering substances from the sample by Dowex column chromatography for accurate assay of cyclic AMP and of cyclic GMP (Marcelo et al., 1979).

TABLE 1. Cyclic Nucleotide Values for Psoriatic and Normal Epidermis reported in the Literature

\begin{tabular}{|c|c|c|c|}
\hline Reference & \multicolumn{2}{|c|}{ Psoriatic } & Normal \\
\hline & \multicolumn{3}{|c|}{ 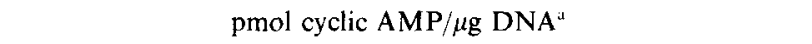 } \\
\hline & Involved & Uninvolved & \\
\hline Voorhees et al., 1972b & $0.40 \pm 0.10(25)$ & $0.70 \pm 0.10(25)$ & $0.50 \pm 0.10(25)$ \\
\hline Voorhees et al., 1973 & $0.72 \pm 0.11(25)$ & $1.08 \pm 0.09(25)$ & $0.86 \pm 0.08(19)^{b}$ \\
\hline Yoshikawa et al., 1975a & $0.196 \pm 0.025(10)$ & $0.186 \pm 0.034(10)$ & not done \\
\hline \multirow[t]{2}{*}{ Marcelo et al., 1979} & $0.198 \pm 0.04(28)$ & $0.148 \pm 0.02(28)$ & $0.367 \pm 0.05(34)$ \\
\hline & \multicolumn{3}{|c|}{ pmol cyclic AMP/mg wet weight } \\
\hline Härkönen et al., 1974 & $2.10 \pm 0.35(14)$ & $1.62 \pm 0.36(13)$ & $0.94 \pm 0.17(11)$ \\
\hline Yoshikawa et al., 1975a & $1.16(10)^{c}$ & $0.91(10)^{\mathrm{c}}$ & not done \\
\hline Wadskov and Søndergaard, 1978 & not done & not done & $1.31 \pm 0.10(8)^{\mathrm{c}}$ \\
\hline \multirow[t]{3}{*}{ Marcelo et al., 1979} & $0.32 \pm 0.046(28)$ & $0.32 \pm 0.045(28)$ & $0.81 \pm 0.097(34)$ \\
\hline & \multicolumn{3}{|c|}{ fmol cyclic GMP/ $\mu \mathrm{g} \mathrm{DNA}^{\mathrm{a}}$} \\
\hline & - & (1) & not don \\
\hline Voorhees et al., 1973 & $11.8 \pm 3.4(12)$ & $6.1 \pm 1.0(12)$ & not done \\
\hline Marcelo et al., 1979 & $11.4 \pm 2.2(28)$ & $4.9 \pm 0.7(28)$ & $6.5 \pm 1.08(34)$ \\
\hline
\end{tabular}

${ }^{\mathrm{a}}$ mean $\pm \mathrm{SEM} ; N$ number is in parenthesis.

${ }^{\mathrm{b}}$ Duell, unpublished data.

"Converted to wet weight from dry weight using a $1: 3$ ratio in the references. 


\subsubsection{Cyclic AMP and Hormonal Stimulation of the Epidermis}

The concentration of cyclic AMP in the epidermis increases after exposure of the animal or tissue slices to $\beta$-adrenergic activation by epinephrine, norepinephrine or isoproterenol (Powell et al., 1971; Marks and Grimm, 1972; Yoshikawa et al., 1975b). Histamine, possibly by $\mathrm{H}_{2}$ receptor activation (Iizuko et al., 1977) and prostaglandin (PG) $\mathrm{E}_{1}$ and $\mathrm{E}_{2}$ (Adachi et al., 1975), possibly by specific receptor binding (Lord et al., 1978), stimulate cyclic AMP synthesis in pig and human epidermis, although not in mouse epidermis (Marks and Rebien, 1972). Duell et al. (1975) demonstrated stimulation of cyclic AMP synthesis by mammalian epidermal slices with adenosine and 5' AMP, again probably through specific receptor interaction. Adachi et al. (1977) have also observed the increase of cyclic AMP content of the epidermis by $5^{\prime}$ AMP, and report specific refractoriness of epidermal slices to 5' AMP. These investigators also reported refractoriness to epinephrine in floating epidermal slices (Adachi et al., 1977), and in an in vivo assay in which hormone was injected intradermally and the epidermis removed by keratome (Iizuka et al., 1978a). Recovery from the epinephrine-induced refractoriness in the in vivo situation began only after 48 hours and was not complete until one week after the initial injection (Iizuka et al., 1978a). Specific refractoriness to PGE and histamine have also been demonstrated in the epidermis (Adachi et al., 1977). The physiological significance of the refractory state of the epidermis in response to those hormones is at present obscure although it may have serious implications in the design of hormone therapy to alleviate the epidermal abnormalities of psoriasis.

\subsection{CyClic AMP AND PSORIASIS}

Since the initial report that changes in the cyclic AMP levels of the epidermis could be involved in the altered state of psoriatic lesional tissue (Voorhees et al., 1972b), several laboratories have examined the content and metabolism of cyclic AMP in lesional and uninvolved epidermis. The cyclic nucleotide values for psoriatic and normal frozen epidermal biopsies reported in the literature are presented in Table 1. Both pmol per $\mu \mathrm{g}$ DNA and per mg wet weight are listed so that all the reported values can be compared. Approximately 100 psoriatic lesional, psoriatic uninvolved, and normal biopsy samples have been processed and assayed for cyclic AMP levels. Seventy to eighty of the assays have been done by this laboratory over the last $6 \mathrm{yr}$. In the final analysis, the data indicate an abnormality in the cyclic AMP system in psoriasis, with a decrease in the lesional tissue levels associated with the disease process, probably at some specific time point in the development of the lesion. The data also suggests that there are time periods during which normal basal, and increased cyclic AMP epidermal content occur, a particular level of cyclic AMP possibly associated with a specific state in lesion development.

In our view, the data presented in Table 1 suggest that both increases and decreases in psoriatic epidermal cyclic AMP levels could be involved in the exacerbation, maintenance and possibly, the remission of the lesion. The precise relationship of cyclic AMP levels with lesion state is as yet unknown, although, as will be later discussed, cyclic AMP can have both positive and negative effects on epidermal growth using in vitro systems.

Besides determining the levels of cyclic AMP in the psoriatic epidermis, investigations of biopsy tissue have suggested that there are changes in the cyclic AMP generating system of lesional epidermis. Involved psoriatic tissue has been reported to demonstrate decreased responsiveness to $\beta$-adrenergic stimuli (Hsia et al., 1972; Yoshikawa et al., 1975b; Iizuka et al., 1978b) and to $\mathrm{PGE}_{1}$ (Aso et al., 1975) and increased responsiveness to histamine (Iizuka et al., 1978b). In addition, lizuka et al. (1978c) have reported that the 'pure' epidermis from lesional tissue showed increases in both high and low km cyclic AMP and cyclic GMP phosphodiesterase activity. These reports suggest that altered cyclic AMP levels in lesional epidermis may be secondary to changes in the cyclic AMP generating and degrading enzyme systems. However, we can not dismiss the possibility 
that the observed changes in the response of whole lesional tissue to $\beta$-adrenergic, PGE and histamine stimulation of cyclic AMP synthesis and the altered phosphodiesterase activity actually reflects a changed cell population, i.e. a larger portion of germinative cells, and is not an actual change in per cell enzyme activity.

Other data implicating changes in cyclic AMP in the manifestation of psoriasis are found in a number of clinical observations. Topical use of papaverine, a phosphodiesterase inhibitor that elevates cyclic AMP in epidermal tissue strips, produces a statistically significant improvement of psoriatic lesions (Stawiski et al., 1975). Topical application of propanolol, a $\beta$-receptor antagonist (Gaylarde et al., 1978) has been reported to cause psoriasiform changes in guinea-pig skin. Intradermal injection of the drug induced a proliferative response in uninvolved psoriatic skin while having no effect on the epidermis from normal volunteers (Wiley and Weinstein, 1977). Psoriasis-like skin reactions have also been seen with practolol, a $\beta_{1}$-receptor antagonist (Tegner, 1976). It is possible that the psoriasis-like skin changes seen with these $\beta$-antagonists reflects some $\beta$-adrenergic-cyclic AMP abnormality in psoriatic skin although other modes of action are possible, such as propranolol acting as a membrane stabilizer and influencing prostaglandin tissue effects (Manku et al., 1977).

\subsection{CYCLIC GMP}

\subsubsection{Metabolism and Control of Epidermal Levels}

Cyclic GMP (guanosine 3',5'-monophosphate), the other cyclic nucleotide shown to have widespread biological function, is present in the epidermis. Cyclic GMP is synthesized from GTP by the enzyme guanylate cyclase. Marks (1973) has identified guanylate cyclase activity in mouse epidermis homogenate supernatant. The cyclase is not stimulated by several $\beta$-agonists, acetylcholine, serotonin, thyroxine or somatotropin. Our attempt to define agents that alter epidermal cyclic GMP levels indicate that norepinephrine, $\mathrm{PGF}_{2 \alpha}$, triamcinolone acetonide, the phosphodiesterase inhibitors 1-methyl-3isobutylxanthine and papaverine, indomethacin and injury do not change epidermal cyclic GMP levels (Marcelo, unpublished data). In our hands, acetylcholine and the cholinergic agonist, carbachol, can increase the epidermal levels of cyclic GMP but the time-course variation, the failure to block the effect with atropine and the demonstration of only a partial block with hexamethonium (nicotinic receptor antagonist), may indicate a non-receptor-specific epidermal cell membrane action with these agents, or the presence of cell refractoriness due to release of cholinergic transmitters during removal of the epidermal tissue by keratome (Marcelo, unpublished data). The only consistently high cyclic GMP value we have observed in our mouse epidermal strip studies is a three- to four-fold increase in epidermis snap frozen immediately after keratoming when compared to epidermis frozen $1-30 \mathrm{~min}$ after removal (floating in buffer at $37^{\circ} \mathrm{C}$ ). The increase in cyclic GMP is partially or completely blocked by either ether or carbon dioxide anesthesia of the animal prior to death and epidermal keratoming (Marcelo, unpublished data). Belman et al. (1978) have reported an increase in epidermal cyclic GMP $36 \mathrm{hr}$ after application of 12-O-tetradecanoyl phorbol-13-acetate (TPA), a tumor promoter and epidermal irritant at high doses. This suggests to us that, while epidermal levels of cyclic GMP may be increased by receptor-mediated action of cholinergic hormones, the epidermal cyclic GMP system can be stimulated by other cell membrane perturbations, perhaps defining interaction of epidermal cell cyclic GMP with rapid membrane-associated phenomenon, i.e. $\mathrm{Ca}^{2+}$ or other ion influx, some oxidation-reduction phenomenon such as those reported by White et al. (1976) in a rat lung fraction or by Haddox et al. (1976) in the lymphocyte.

Marks and Raab (1974) have studied the cyclic GMP phosphodiesterase activity of mouse epidermis supernatants and have reported one soluble phosphodiesterase activity hydrolyzing cyclic GMP, separate from another soluble fraction that degrades cyclic AMP. Rusin et al. (1978) have demonstrated cyclic GMP phosphodiesterase activity in 
mouse epidermal homogenates which was not inhibited by Ro 20-1724, an inhibitor of cyclic AMP in mouse epidermal slice and homogenate systems, suggesting the existence of a separate system for degrading epidermal cyclic GMP.

\subsection{ASSAY}

As with cyclic AMP, the levels of cyclic GMP are extremely small, ranging from 5$7 \mathrm{fmol}$ per $\mu \mathrm{g}$ DNA. The RIA assay using a highly specific antibody generated to a succinylated derivative of cyclic GMP in rabbits and goats (Marcelo et al., 1979), is used to assay for cyclic GMP. The sensitivity of the assay is increased to meet the requirements of the extremely low cyclic GMP tissue levels by acetylation as described by Harper and Brooker (1975). Using the acetylation technique, the standard curve for a cyclic GMP RIA runs from 1-200 fmol, and requires extensive purifications of the epidermal samples (Marcelo et al., 1979).

\subsubsection{Cyclic GMP in Psoriasis}

As presented in Table 1, the levels of cyclic GMP have been determined in forty psoriatic lesional and uninvolved, and thirty four normal epidermal biopsies. The results indicate a statistically significant two-fold increase in the epidermal cyclic GMP levels of the lesional tissue. This increase in cyclic GMP has been postulated to be associated with the increased proliferative state of the psoriatic lesional epidermis (Voorhees et al., 1973). However, the function or cause of the increased cyclic GMP levels in psoriasis is not as simple as postulated in 1973 since Marks (1978) has demonstrated increased proliferative activity in uninvolved psoriatic tissue that does not show any increase in assayable cyclic GMP levels (Table 1). Moreover, in non-psoriatic proliferative systems, i.e. TPA stimulated epidermal proliferation, the role of cyclic GMP remains undefined (Mufson et al., 1977; Belman et al., 1978).

\subsection{Function of CyClic Nucleotides in In Vitro Systems}

Investigations of the cyclic AMP system in the epidermis has shown association of several hormonal receptors with changes in epidermal levels of this cyclic nucleotide, and both cyclic AMP and cyclic GMP have been implicated in the hyperproliferative and abnormally functioning psoriatic epidermis. These investigations suggest that changes in epidermal cyclic nucleotides can influence epidermal cell function.

\subsubsection{Cyclic AMP}

Several in vitro studies designed to define the mode of cyclic AMP-related epidermal cell function(s) have been reported. Dibutyryl cyclic AMP and isoproterenol have been shown to inhibit the $\mathrm{G}_{2}$ phase of the epidermal cell cycle in an in vitro 5 -hr mouse ear assay (Voorhees et al., 1972c). These results were confirmed and extended by Harper et al. (1974), Flaxman and Harper (1975) using organ and explant (Chopra, 1977) human skin cultures. In addition, Chopra (1977), employing the human explant culture system reported a 93 per cent inhibition of the labeling index 4 days after exposure of the cultures to $1 \mathrm{mM}$ dibutyryl cyclic AMP plus the PDE inhibitor theophylline. Delescluse et al. (1974) have demonstrated inhibition of adult guinea-pig ear cultures by cyclic AMP elevating agents and analogues, an effect associated with increased differentiation.

Green, using a neonatal human keratinocyte system that employs a 3T3 feeder layer to support the proliferation and extensive differentiation of the cultures (Rheinwald and Green, 1977; Sun and Green, 1976; and Rice and Green, 1978) reports a positive correlation between four agents known to increase cellular cyclic AMP levels and increases in the growth of the colonies of cultured keratinocyte (Green, 1978). 
We have investigated the effect of dibutyryl cyclic AMP, 8-bromo cyclic AMP and cholera toxin plus a phosphodiesterase inhibitor on a neonatal mouse primary keratinocyte system which initiate predominantly as basal cells and show progressive specialization (differentiation) over time (Marcelo et al., 1978). The results indicate that the cyclic AMP elevating agents cause a dose- and time-dependent stimulation of keratinocyte proliferation (Marcelo, 1979). The treated cells show accelerated stratification, specialization and shedding of top cell layers. Moreover, the data indicated that cyclic GMP was not involved in the stimulation of proliferation observed with the cyclic AMP elevating agents. These results indicate that increased cyclic AMP levels are associated with keratinocyte culture proliferation and accelerated specialization in neonatal systems and can inhibit epidermal cell growth in adult human in vitro systems. The difference in response between neonatal and adult epideraml cell response to elevated cyclic AMP levels may result from differences between in vitro techniques, species differences or a different cyclic AMP control mechanism operating in adult versus neonatal cells. Our preliminary studies using adult keratinocyte cultures on collagen gels show that elevated levels of cyclic AMP can both stimulate and inhibit the cultures. The difference between the neonatal and adult system, at least in vitro, seems to be in both the dose- and timeresponse curves of the cells (Marcelo and Duell, 1979). It is possible that both the stimulatory and inhibitory effects of cyclic AMP on epidermal cell proliferation can be exploited to control the cutaneous symptoms of psoriasis.

\subsubsection{Cyclic GMP}

Using the neonatal mouse keratinocyte culture system, we have demonstrated that $10^{-7}$ M 8-bromo cyclic GMP enhances keratinocyte specialization without any effect on cell proliferation (Marcelo, 1979). This suggests a role for cyclic GMP in the specialization of the neonatal epidermis. The role of this cyclic nucleotide in adult systems is yet to be defined.

\section{THE ARACHIDONIC ACID AND PROSTAGLANDIN SYSTEM}

\subsection{Metabolism and AsSay}

Prostaglandins are 20-carbon monocarboxylic acids with five membered cyclopentane rings and are synthesized in cells from essential polyunsaturated precursor fatty acids, i.e., arachidonic acid (20:4) and 8,11,14-eicosatrienoic acid (20:3). Arachidonic acid and its biotransformation products, and $20: 3$ and its products are in skin, although $20: 3$ and 20:4 occur in a 1-10 ratio (Wilkinson and Walsh, 1977). The precursor acids for prostaglandin synthesis arise from several intracellular lipid pools, one being the membrane phospholipids. The enzyme responsible for release of fatty acid precursors for prostaglandin biosynthesis is phospholipase $\mathrm{A}_{2}$ (see Galli et al., 1978 for detailed reviews). The precursor fatty acids can be introduced into membrane phospholipids by esterification. When the precursor fatty acids are in the 'free' non-membrane bond form, they are acted upon by several enzyme systems to form a group of biologically active molecules (Fig. 1). Arachidonic acid, the most abundant free fatty acid in the skin, is acted upon by two enzymes, each resulting in a separate series of products. One enzyme is fatty acid cyclooxygenase which forms the endoperoxides $\left(\mathrm{PGG}_{2}\right.$ and $\left.\mathrm{PGH}_{2}\right)$ and the products thromboxane $A_{2}$ and $B_{2}$, and $P_{2} E_{2}, P_{2 \alpha}$, and $P_{2} D_{2}$ (Samuelsson, 1976). The other enzyme, lipoxygenase results in the formation of the products HPETE (hydroperoxy-HETE) and HETE (12-L-hydroxy-5,8,10,14-eicosatraenoic acid (Samuelsson, 1976). Prostaglandins and their precursors are present in very small amounts in tissues. To assay for these compounds, mass spectrometric, gas chromatography-mass spectrometric and radioimmunoassays have been developed (Samuelsson and Paoletti, 1976; Lindgren et al., 1974). 


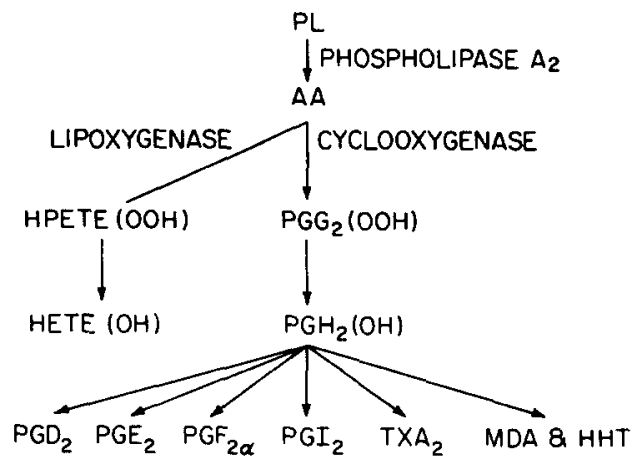

FIG. 1. Arachidonic acid and its major biotransformation products. PL: membrane phospholipids; AA: free arachidonic acid; HETE: 12-L-hydroxy-5,8,10,14-eicosatraenoic acid; HPETE: hydroperoxy-HETE; MDA: malondialdehyde. There is a 26-fold increase in free arachidonic acid and an 86-fold increase in HETE in psoriatic lesional epidermis. PGE $_{2}$ is increased 40 per cent while $\mathrm{PGF}_{2 \alpha}$ is elevated 80 per cent in psoriasis (Hammarström et al., 1975).

\subsection{Prostaglandins and Their Precursors in the Skin}

In rat skin, two major essential fatty acids are linoleic and arachidonic acids both found in the phospholipid component (Prottey, 1977). Arachidonic acid is the most important precursor of the prostaglandins (Prottey, 1977) and the prostaglandins produced by the microsomal fraction of skin are $\mathrm{PGF}_{2 \alpha}, \mathrm{PGE}_{2}$, and $\mathrm{D}_{2}(20: 4$ or arachidonic acid the precursor) (Kingston and Greaves, 1976). However, Wilkinson and Walsh (1977) have reported that $20: 3$ is also converted to $\mathrm{PGE}_{1}, \mathrm{PGD}_{1}$, and $\mathrm{PGF}_{1 a}$ by mouse skin homogenates.

$\mathrm{PGE}_{2}$ is the major prostaglandin synthesized by human skin homogenates and arachidonic acid is the major 20-carbon acid esterified into the phospholipid fraction (Jonsson and Anggard, 1972). The enzyme activity is localized in the microsomal fraction (Ziboh, 1973). $\mathrm{PGE}_{2}$ has been implicated in cutaneous inflammatory response to injury. Anggard and Jonsson (1972) demonstrated that $\mathrm{PGE}_{2}$ is formed in the skin following a burn injury. Jørgensen and Søndergaard (1973) studying the response of human cutaneous blood vessels to intradermal injection of $\mathrm{PGE}_{1}$, reported that this prostaglandin can mediate vascular permeability in sustained acute inflammation of the skin and thus may be responsible for sustained skin inflammation. Søndergaard et al. (1973) have reported a similar effect with $\mathrm{PGE}_{1}$ on human skin.

The essential fatty acid-deficient rat (Ziboh and Blank, 1973) and hairless mouse (Lowe et al., 1977a) systems have been used to study the functional significance of arachidonic and 20:3 fatty acids, and their products in the epidermis. The cutaneous features of the condition are thickening of the skin and scaling, acanthosis, hyperkeratosis and increased epidermal mitotic indices that are relieved by topical application of $\mathrm{PGE}_{2}$ and linoleic acid (Ziboh et al., 1972; Lowe and Stoughton, 1977a; Lowe, 1977). The decrease in the mitotic rate of EFA deficient epidermis by topical application of $\mathrm{PGE}_{2}$ suggests control of epidermal proliferation by the cellular $\mathrm{PGE}_{2}$ content. However, the direction of the proliferative response to $\mathrm{PGE}_{2}$ varies since in normal hairless mice topical $\mathrm{PGE}_{2}$ stimulates epidermal proliferation (Lowe and Stoughton, 1977b).

\subsection{The Arachidonic Acid and Prostaglandin System in Psoriasis}

The epidermal phospholipids are elevated in psoriasis, a change possibly connected with alterations of membrane-bound phospholipids (Tsambaos et al., 1977). How these changes may be involved in lesional epidermal cell membrane structure and function is unknown. The changes in psoriatic lipid metabolism are not those seen in the EFAdeficient condition although the general symptoms, i.e., scaling, increased mitotic rate, 
etc., are similar. In the EFA deficient state 20:3 and 20:4 fatty acids and their products are absent, while in psoriatic lesional tissue there is a 40 and 80 per cent increase in the lesional levels of $\mathrm{PGE}_{2}$ and $\mathrm{PGF}_{2 x}$, respectively (Hammarström et al., 1975). These changes in prostaglandins are not as pronounced as the 26-fold increase in free arachidonic acid and 82-fold increase in HETE found in the lesional tissue. This increase in free arachidonic acid and HETE in psoriasis suggests some changes in the psoriatic epidermal cell control of the enzymes involved in arachidonic acid biotransformation. One possible causative mechanism for this change is the presence of an endogenous inhibitor of prostaglandin synthesis (Pennys et al., 1977) that may be exaggerated in psoriasis (Simon et al., 1977). How a comparatively decreased rate of prostaglandin synthesis in association with an accelerated free arachidonic acid metabolism to a predominant HPETE and HETE system can affect epidermal cell functions is unknown, although the biotransformation process itself may be involved in the changes observed in epidermal cell function. The fact that glucocorticoids, which reduce the levels of both arachidonic acid and HETE in the tissue (Hammarström et al., 1977), is therapeutic in psoriasis supports the theory that these compounds may be involved in the disease process.

\section{POLYAMINE SYSTEM}

The diamine putrescine, and the polyamines spermidine and spermine are found in all living material (Raina and Jänne, 1975). These amines are polycationic in nature, are elevated in actively proliferating tissues and bind tightly to nucleic acids suggesting an interrelationship between them and the synthesis of nucleic acids and proteins (Tabor and Tabor, 1976; Knutson and Morris, 1978). A requirement for intracellular polyamine concentration during the $G_{1}$ to $S$ transmission in $\mathrm{CHO}$ cells has been reported by Fuller et al., (1977). This association of $\mathrm{G}_{1}$ to $S$ transition with induction of polyamine biosynthesis has been associated with enhanced cell cyclic AMP levels suggesting that cyclic AMP may regulate polyamine synthesis, at least in some systems (Hibasami et al., 1977; Costa, 1978). Fluctuations in polyamine levels have been reported in a number of disease states including cancer (Russell, 1973), cystic fibrosis and psoriasis (Russell and Durie, 1978, and Russell et al., 1978).

\subsection{Metabolism and ASSaY IN THE SKIN}

As diagrammed in Fig. 2, the diamine putrescine is synthesized from ornithine, the reaction catalyzed by ornithine decarboxylase (ODC). Putrescine stimulated S-adenosylL-methionine decarboxylase and spermidine stimulated S-adenosyl-L-methionine decarboxylase (SAMD) are involved in the synthesis of spermidine and spermine, respectively, from putrescine with ODC being the rate-limiting enzyme for the overall synthesis of these naturally occurring polyamines (Jänne et al., 1978).

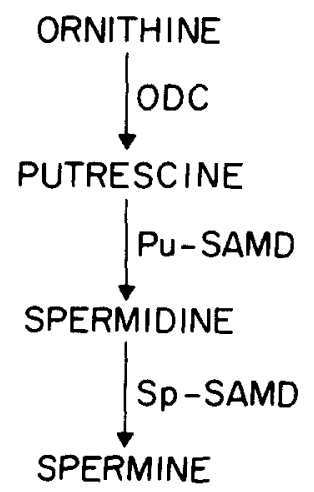

FIG. 2. The diamine and polyamine biosynthetic system. ODC: ornithine decarboxylase: PuSAMD: putrescine stimulated $S$-adenosyl-L-methionine decarboxylase, synthesis of spermidine; Sp-SAMD: Spermidine stimulated $S$-adenosyl-L-methionine decarboxylase, synthesis of spermine. 
In cells, polyamines occur in the free form while polyamine conjugates and metabolites are found in urine and serum (Daves, 1978, contains extensive detailed reviews). Assay of polyamine involves fluorometric assay of dansyl derivatives (acetyl conjugates) separated by thin layer chromatography or mass spectrometric analyses of the conjugates (Bachrach, 1978). High pressure liquid chromatography of the dansyl derivatives has been described (Abdel-Monem et al., 1978) and Russell (1973) has described an automated system using an amino acid analyzer.

\subsection{Polyamines in the Skin and IN Psoriasis}

Ornithine decarboxylase has been characterized in rat skin and reported to be increased in stimulated follicular proliferation and to fluctuate in response to changes in dietary protein (Morrison and Goldsmith, 1978). Wound healing (Mizutani et al., 1974) and ultraviolet irradiation (Lowe et al., 1978) increase ODC activity in the skin and epidermal injury by topical application of a series of phorbol esters (i.e., TPA) is associated with induction of ODC and SAMD (O'Brien et al., 1975). Another type of tumor promotion, wounding, also caused induction of ODC activity (Clark-Lewis and Murray, 1978) suggesting a correlation between enhanced polyamine biosynthesis and the epidermal growth involved in the tumor promoting process. This correlation may not be absolute since Murray (1978) reported enhancement of epidermal cell mitosis with TPA in Vitamin $\mathrm{B}_{6}$-deficient mice where ODC activity is reduced due to lack of pyridoxal 5'-phosphate, an essential co-factor for ODC activity (Raine and Jänne, 1975). Murray (1978) interprets this data as not supporting a concrete cause-effect relationship between ODC and induction of proliferation in mouse epidermis.

The spermidine and spermine levels in blood samples from psoriatic patients were found to be two to three times those of control subjects (Proctor et al., 1975). Grosshans and Henry (1978) reported that the levels of all the polyamines were significantly elevated in the lesional tissue while the uninvolved psoriatic tissue demonstrated an increase in only the putrescine levels. In a simultaneous study, Russell et al. (1978) found that the putrescine, spermidine and spermine levels were higher in lesional than in uninvolved psoriatic tissue, and that uninvolved tissue levels of these same three polyamines are higher than those of normal volunteer epidermis. The urine from psoriatic patients reflected the increased epidermal polyamine levels, and a six-fold increase in epidermal ODC and SAMD were associated with the increased putrescine, spermidine and spermine levels. The increased activity of polyamine biosynthetic enzymes were significantly decreased by application of glucocorticoids to the lesions for $24 \mathrm{hr}$, indicating that while elevated polyamine biosynthesis is associated with the active lesion, efficacious treatment reduces the activity of these enzymes in the epidermis. Russell et al., (1978) suggest that use of ODC and SAMD inhibitors may be used as part of a therapeutic program to control the disease.

\section{CHANGES IN EPIDERMAL CELL HOMEOSTASIS AND THE CYCLIC NUCLEOTIDE, PROSTAGLANDIN AND POLYAMINE SYSTEMS}

Psoriasis is characterized by changes in a number of modulatory systems, any one or all of which may be involved in the cutaneous manifestation of the disease. The level of cyclic AMP seems to be decreased in the psoriatic epidermis and a decreased lesional cyclic AMP concentration when compared with the uninvolved epidermis from the same patient has been reported in several studies (Table 1). Cyclic GMP, a second biologically active cyclic nucleotide, is increased approximately two-fold in the lesional areas when compared to both uninvolved and normal volunteer epidermis.

A less sensitive $\beta$-adrenergic system may be responsible, in part, for the lowered levels of cyclic AMP in the lesional tissue. Moreover, this decrease in the total lesional cyclic AMP may contribute to the markedly increased proliferation of the lesional tissue. The 
development of psoriasiform lesions and increased proliferation in the presence of $\beta$-adrenergic antagonists supports the theory of a malfunctioning $\beta$-adrenergic receptor system in psoriasis.

In vitro investigations of the effect of cyclic AMP on epidermal cells in culture has added a new dimension to the possible mechanism of effect of cyclic nucleotides in psoriasis. In vitro investigations have demonstrated that cyclic AMP can both stimulate (the neonatal mouse, and neonatal and adult human) and decrease the growth (adult human, guinea-pig ear) of the epidermal cell, suggesting a bidirectional effect by this cyclic nucleotide. A precise definition of the effects of cyclic AMP and cyclic GMP on psoriatic lesional and uninvolved tissue is still a missing part in the puzzle that must be completed in order to decipher the role of cyclic nucleotides in this cutaneous disorder.

The levels of putrescine, spermine and spermidine are elevated in the lesional epidermal tissue concomitant with an increase in ODC activity. The increased ODC and polyamine levels correlate with the enhanced proliferative activity of the tissue (Russell et al., 1978) and, if the result of studies in other systems is applicable to the skin, should correlate with elevated cyclic AMP levels. Roseeuw et al. (1979) have demonstrated some correlation between increased ODC- and cyclic AMP-stimulated keratinocyte growth. However, the correlation occurs in only approximately 70 per cent of the experiments, suggesting a casual relationship, at best, between the cyclic nucleotide and polyamine systems, at least in the in vitro situation. However, these in vitro studies do not disprove the possible occurrence of a critical link between the cyclic nucleotide and polyamine system in the exacerbation of psoriasis. For example, it is possible that while cyclic AMP may be decreased when the bulk DNA or protein of a lesion is considered, this cyclic nucleotide may be localized at increased concentrations in key regulatory areas (basal cells). It is possible that a functional connection among cyclic AMP, polyamines and epidermal cell proliferation may occur only at key time points in psoriatic skin.

The activity and induction of the polyamine biosynthetic system has recently been linked, in a mandatory mode, with stimulated epidermal cell proliferation. Verma et al. (1977) have reported that TPA-induced ODC activity is blocked by indomethacin, an inhibitor of prostaglandin synthesis. This block of enzyme induction is overcome by addition of $\mathrm{PGE}_{2}$ application. These results indicate that TPA induction of ODC activity and proliferation in the epidermis can be linked in a cause-effect series with some as yet unknown $\mathrm{PGE}_{2}$-requiring step, at least in mouse epidermis.

To what extent the polyamine-prostaglandin-cyclic-nucleotide-proliferation model systems, both in vivo and in vitro, reflect the psoriatic epidermal cell state is unknown. However, investigations of the functional role of these mediators in model systems will help to decipher the functional interaction of these modulators in the epidermis, and possibly lead to formulation of safe and efficacious therapeutic programs to control this disease.

Acknowledgement-This work was supported by grants from NIADD No. AM-15740, and I ROI AM-26009-01.

\section{REFERENCES}

Abdel-Monem, M. M., Ohno, K., Newton, N. E. and Weeks, C. E. (1978) Thin-layer chromatography and high-pressure liquid chromatography of the dansyl polyamines. In Advances in Polyamine Research, Vol. 2, pp. 37-49, Campbell, R., Morris, D., Bartus, D., Daves, C. and Bartus, F. (eds). Raven Press, New York.

Adachi, K., IIZUKa, H., HalPRiN, K. M. and LeVINE, V. (1977) Specific refractoriness of adenylate cyclase in skin to epinephrine, prostaglandin E, histamine and AMP. Biochim. biophys. Acta 497: 428-436.

Adachi, K., Yoshikawa, K., Halprin, K. M. and Levine, V. (1975) Prostaglandins and cyclic AMP in epidermis. Br. J. Derm. 92: 381-388.

ANGGARD, E. and Jonsson, C. E. (1972) Formation of prostaglandins in the skin following a burn injury. In Prostaglandins in Cellular Biology pp. 269-291, Ramwell, P. W. and Pharriss, B. B. (eds). Vol. 1 Plenum Press, New York.

Aso, K., OREnberg, K. and Farber, E. M. (1975) Reduced epidermal cyclic AMP accumulation following prostaglandin stimulation: its possible role in the pathophysiology of psoriasis. $J$. invest. Derm. 65 : 375-378 
BaCHRaCh, U. (1978) Analytical methods for polyamines. In Advances in Polyamine Research, Vol. 2, pp. 5-11, Campbell, R., Morris, D., Bartus, D., Daves, G. and Bartus, F. (eds). Raven Press, New York.

Bachrach, U., Katz, A. and Hochman, J. (1978) Polyamines and protein kinase I. Induction of ornithine decarboxylase and activation of protein kinase in rat glioma cells. Life Sci. 22: 817-822.

Beckman, L., Bergdahl, B., Cedergren, B. and Liden, S. (1977) Genetic markers in psoriasís. Acta derm.vener., Stockh. 57: 247-251.

Belman, S., Troll, W. and Garte, S. (1978) Effect of phorbol myristate acetate on cyclic nucleotide levels in mouse epidermis. Cancer Res. 38: 2978-2982.

Byus, C., Klimpel, G. R., Lucas, D. O. and Russell, D. H. (1978). Ornithine decarboxylase induction in mitogen stimulated lymphocytes is related to the specific activation of type I adenosine cyclic 3',5'-monophosphate-dependent protein kinase. Molec. Pharmac. 14: 431-441.

Chopra, D. P. (1977) Effects of theophylline and dibutyryl cyclic AMP on proliferation and keratinization of human keratinocytes. Br. J. Derm. 96: 255-262.

Clark-Lewis, I. and Murray, A. W. (1978) Tumor promotion and the induction of epidermal ornithine decarboxylase activity in mechanically stimulated mouse skin. Cancer Res. 38: 494-497.

Corbin, J. D. and Lincoln, T. M. (1978) Comparison of cAMP- and cGMP-dependent protein kinases. In Advances in Cyclic Nucleotide Research, Vol. 9, pp. 159-170, GeOrGe, W. J. and IGNArRo, L. (eds). Third International Conference on Cyclic Nucleotides, New Orleans, 1977. Raven Press, New York.

Costa, M. (1978) Cyclic AMP-dependent regulation of ornithine decarboxylase activity in chinese hamster ovary cells maintained with a salts/glucose medium. J. Cyclic Nucleotide Res. 5: 374-387.

DAVES, G. D., JR (1978) Section introduction: Analysis of polyamines. In Advances in Polyamine Research, Vol. 2, pp. 3-4, Campbel.l, R., Morris, D., Bartus, D., Daves, G. and Bartus, F. (eds). Raven Press, New York.

Delescluse, C., Colburn, N. H., Duell, E. A. and Voorhees, J. J. (1974) Cyclic AMP-elevating agents inhibit proliferation of keratinizing guinea pig epidermal cells. Differ. 2: 343-350.

Duell, E., BAZner, W. and VoorheEs, J. (1975) Adenosine (Ado) and 5'AMP increase the cellular levels of cyclic AMP (cAMP) in the epidermis (E) of mammalian skin. Fed. Proc. 34 : 333.

Dueld, E. A., VoORHEes, J. J., Kelsey, W. H. and HAYes, E. (1971). Isoproterenol-sensitive adenyl cyclase in a particulate fraction of epidermis. Arch. Derm. 104: 601-610.

Farber, E. M., Nall, M. L. and Watson, W. (1974) Natural history of psoriasis in 61 twin pairs. Arch Derm. 109: $207-211$

FlaXMAN, B. A. and HARPER, R. A. (1975) In vitro analysis of the control of keratinocyte proliferation in human epidermis by physiological and pharmacologic agents. $J$. invest. Derm. 65: 52-59.

Fuller, D. J. M., Gerner, E. W. and Russell, D. H. (1977) Polyamine biosynthesis and accumulation during the $\mathrm{G}_{1}$ to $\mathrm{S}$ transition. J. Cell. Physiol. 93: 81-88.

Galli, C., Galli, G. and Porcellati, G. (1978) Phospholipases and prostaglandins. In Advances in Prostaglandin Research, (Vol. 3), Raven Press, New York.

Gaylarde, P. M., Brock, A. P. and Sarkany, I. (1978) Psoriasiform changes in guinea-pig skin from propranolol. Clin. Exp. Derm. 3: 157-160.

George, W. M. and Ignarro, L. (1978) Advances in Cyclic Nucleotide Research, Vol. 9, Third International Conference on Cyclic Nucleotides held in New Orleans, 1977. Raven Press, New York.

Gilman, A. G. (1970) A protein binding assay for adenosine 3',5'-cyclic monophosphate. Proc. natn. Acad. Sci. U.S.A. 67: 305-312.

GREeN, H. (1978) Cyclic AMP in relation to proliferation of the epidermal cell: A new view. Cell 15: 801-811.

Grosshans, E. and Henry, M. (1978) Skin polyamine levels in psoriasis-the effect of therapy. Invest. Derm. 70 227.

Haddox, M. K., Furcht, L. T., Gentry, S. R., Moser, M. E., Stephenson, J. H. and Goldberg, N. D. (1976) Periodate-induced increase in cyclic GMP in mouse and guinea pig splenic cells in association with mitogenesis. Nature 262: 146-148.

Hammarström, S., Hamber, M., Duell, E. A., Stawiski, M. A., Anderson, T. F., and Voorhees, J. J. (1977) Glucocorticoid in inflammatory proliferative skin disease reduces arachidonic and hydroxyeicosatetraenoic acids. Science 197: 994-995.

Hammarström, S., Hamberg, M., Samuelsson, B., Duell, E. A., Stawiski, M., and Voorhees, J. J. (1975) Increased concentrations of nonesterified arachidonic acid, 12-L-hydroxy-5,8,10,14-eicosatetraenoic acid, prostaglandin $\mathrm{E}_{2}$ and prostaglandin $\mathrm{F}_{2 x}$ in epidermis of psoriasis. Proc. natn Acad. Sci. U.S.A. 72 : $5130-5134$.

Härkönen, M., Hopsu-Havu, V. and RaIJ, K. (1974). Cyclic adenosine monophosphate, adenyl cyclase and cyclic nucleotide phosphodiesterase in psoriatic epidermis. Acta derm.-vener. Stockh. 54: 13-18.

HARPER, J. F. and BRoOKer, G. (1975) Femtomole sensitive radioimmunoassay for cyclic AMP and cyclic GMP after 2'O-acetylation by acetic anhydride in aqueous solution. J. Cyclic Nucleotide Res. 1: 207-218.

Harper, R. A., Flaxman, B. A. and Chopra, D. P. (1974) Effect of pharmacological agents on human keratinocyte mitosis in vitro-I. inhibition by adenine nucleotides, Proc. Soc. exp. Biol. Med. 146: 1032-1036.

HARPER, R. A., Rispler, J. and URBANEK, R. W. (1978) DNA synthesis among uninvolved and involved psoriatic epidermal cells and normal epidermal cells in vitro. $J$. invest. derm. 70: 254-256.

Hibasami, H., Tanaka, M., Nagai, J. and Ikeda, T. (1977) Changes in ornithine decarboxylase activity and cyclic adenosine-3'-5'-monophosphate concentrations during the cell cycle of synchronized BHK cells. Aust. J. Exp. Biol. med. Sci. 55: 379-383.

Hochman, J., Katz, A. and BaChraCh, U. (1978) Polyamines and protein kinase-II. Effect of polyamines on cyclic AMP-dependent protein kinase from rat liver. Life Sci. 22: 1481-1484.

Hsia, S. L., Wright, R., StePhen, M. S., Mandy, H. and Halprin, K. M. (1972) Adenyl cyclase in normal and psoriatic skin. $J$. invest. Derm. 59: 109-113.

IIZUKA, H., ADACHI, K., HALPRIN, K. M. and Levine, V. (1978a) Epinephrine activation of pig skin adenylate cyclase in vivo and subsequent refractoriness to activation. $J$. invest. Derm. 70: 119-122. 
Iizuka, H., ADACHI, K., HalPRin, K. M. and Levine, V. (1977). Epidermal adenylate cyclase: stimulation of the histamine $\left(\mathrm{H}_{2}\right)$ receptor by tolazoline. J. invest. Derm. 69: 442-445.

IIzukA, H., ADACHI, K., Halprin, K. M. and Levine, V. (1978b) Cyclic AMP accumulation psoriatic skin: differential responses to histamine, AMP and epinephrine by the uninvolved and involved epidermis. $J$. invest. Derm. 70: 250-253.

Iizuka, H., ADachi, K., Halprin, K. M. and Levine, V. (1978c) Cyclic nucleotide-phosphodiesterase in the uninvolved and involved skin of psoriasis. J. invest. Derm. 70: 246-249.

JÄNNE, J., Pösö, H. and RAINA, A. (1978) Polyamines in rapid growth and cancer. Biochim. biophys. Acta 473 241-293.

Jonsson, C. E. and ANGGARD, E. (1972) Biosynthesis and metabolism of prostaglandin $\mathrm{E}_{2}$ in human skin. Scand. J. clin. Lab. Invest. 29: 289-296.

Jørgensen, H. P. and SøndergaARd, J. (1973) Vascular responses to prostaglandin $\mathrm{E}_{1}$. Acta derm.-vener., Stockh. 53: 203-206.

Kingston, W. P. and Greaves, M. W. (1976) Factors affecting prostaglandin synthesis by rat skin. Prostaglandins 12: $51-69$.

Knutson, J. C. and Morris, D. R. (1978) Cellular polyamine depletion reduces DNA synthesis in isolated lymphocyte nuclei. Biochim. biophys. Acta 520: 291-301.

Kumar, R., Solomon, L. M., CobB, J. and Schreckenberger, A. (1976) Adenosine 3',5'-monophosphate-dependent protein kinases of neonatal human skin. J. invest. Derm. 66: 14-16.

Kumar, R., Tao, M., Piotrowski, R. and Solomon, L. (1973) Multiple forms of adenosine 3',5'-cyclic monophosphate-dependent protein kinase from monkey skin. Biochim. biophys. Acta 315: 66-72.

Kumar, R., TAO, M. and Solomon, L. (1972) Adenosine 3',5'-cyclic monophosphate-stimulated protein kinase from human skin. J. invest. Derm. 59: 196-200.

Kumar, R., TAO, M. and SOlOMON, L. (1971) Cyclic 3'5'-adenosine monophosphate stimulated protein kinase from human skin. $J$. invest. Derm. 57: 312-315.

LindGRen, A., Kindahl, $H$. and Hammarström, S. (1974) Radioimmunoassay of prostaglandins $E_{2}$ and $F_{2 \alpha}$ in cell culture media utilizing antisera against prostaglandins $\mathrm{F}_{2 \beta}$ and $\mathrm{F}_{2 x}$. FEBS Letts 48: 22-25.

LORD, J. T., ZIBOH, V. A. and W ARREN, S. K. (1978) Specific binding of prostaglandins $E_{2}$ and $F_{2 x}$ by membrane preparations from rat skin. Endocrinology 102: 1300-1309.

LOWE, N., Verma, A. K. and Boutwell, R. K. (1978) Ultraviolet light induces epidermal ornithine decarboxylase activity. $J$. invest. Derm. $71: 417-418$.

LowE, N. J. (1977) Essential fatty acid deficient hairless mouse: the effects of topical agents on the epidermis. Br. J. Derm. 97: 39-47.

Lowe, N. J. and Stoughton, R. B. (1977a) Essential fatty acid deficient hairless mouse: a model of chronic epidermal hyperproliferation. Br. J. Derm. 96: 155-162.

Lowe, N. J. and Stoughton, R. B. (1977b) Effects of topical prostaglandin $\mathrm{E}_{2}$ analogue on normal hairless mouse epidermal DNA synthesis. J. Invest. Derm. 68: 134-137.

Manku, M. S., Horrobin, D. F., Ally, A. I., Karmali, R. A., Karmazyn, M. and Morgan, R. O. (1977) Effects of propranolol on the responses of the rat stomach strip to prostaglandin $\mathrm{E}_{2}$. Prostaglandins 14: 273-277.

Marcelo, C. L. (1979) Differential effects of cAMP and cGMP on in vitro epidermal cell growth. Exp. Cell Res. 120: $201-210$

Marcelo, C. L. and Duell, E. A. (1979) Cyclic AMP stimulates and inhibits adult human epidermal cell growth. J. invest. Derm. 72: 279.

Marcelo, C. L., Duell, E. A., Stawiski, M. A., Anderson, T. F. and Voorhees, J. J. (1979) Cyclic nucleotide levels in psoriatic and normal keratomed epidermis. J. invest. Derm. 72: 20-24.

Marcelo, C. L., Kim, Y. G., Kaine, J. L. and Voorhees, J. J. (1978) Stratification, specialization, and proliferation of primary keratinocyte cultures. J. Cell Biol. 79: 356-370.

MARKS, F. and RAAB, I. (1974) The second messenger system of mouse epidermis-IV. cyclic AMP and cyclic GMP phosphodiesterase. Biochim. biophys. Acta 334: 368-377.

MARKs, F. (1973) The second messenger system of mouse epidermis-III. Guanyl cyclase. Biochim. biophys. Acta 309: 349-356.

MarKs, F. and Rebien, W. (1972) The second messenger system of mouse epidermis-I. Properties and $\beta$-adrenergic activation of adenylate cyclase in vitro. Biochim. biophys. Acta $284: 556-567$.

MaRKS, F. and Grimm, W. (1972) Diurnal fluctuation and $\beta$-adrenergic elevation of cyclic AMP in mouse epidermis in vivo. Nature New Biol. 240: 178-179.

MARKS, R (1978) Epidermal activity in the involved and uninvolved skin of patients with psoriasis. Br. J. Derm. 98: $399-404$.

Mizutani, A., Inque, H. and Takeda, Y. (1974) Changes in polyamine metabolism during wound healing in rat skin. Biochim. biophys. Acta 338: 183-190.

Morrison, D. M. and Goldsmith, L. A. (1978) Ornithine decarboxylase in rat skin. J. invest. Derm. 70 309-313.

Mufson, R. A., Astrup, E. G., Simsiman, R. C. and Boutwell, R. K. (1977) Dissociation of increases in levels of $3^{\prime}, 5^{\prime}$-cyclic AMP and 3',5'-cyclic GMP from induction of ornithine decarboxylase by the tumor promoter 12-O-tetradecanoyl phorbol-13-acetate in mouse epidermis in vivo. Proc. natn Acad. Sci. U.S.A. 74 $657-661$.

MurRaY, A. W. (1978) Induction of epidermal cell proliferation by a tumor promoter in vitamin $\mathbf{B}_{6}$-deficient mice. Experientia 34: 691.

Murray, A. W. and Rogers, A. (1978) Calcium-dependent protein modulator of cyclic nucleotide phosphodiesterases from mouse epidermis. Biochem. J. 176: 727-732.

O'Brien, T. G., Simsiman, R. C. and Boutwell, R. K. (1975) Induction of the polyamine-biosynthetic enzymes in mouse epidermis and their specificity for tumor promotion. Cancer Res. 35: 2426-2433.

PenNys, N. S., LoRd, J. T., Ziboh, V. A. and Simon, P. (1977) Inhibitor(s) of prostaglandin biosynthesis and epidermal injury. Prostaglandins 14: 355-362 
Powell, J. A., Duell, E. A. and Voorhees, J. J. (1971) Beta adrenergic stimulation of endogenous epidermal cyclic AMP formation. Archs. Derm. 104: 359-365.

Proctor, M., Fletcher, H., Shukla, J. and Rennert, O. (1975) Elevated spermidine and spermine levels in the blood of psoriasis patients. J. invest. Derm. 65: 409-411.

ProtteY, C. (1977) Investigation of functions of essential fatty acids in the skin. Br. J. Derm. 97: 29-38.

RAINE, A. and JÄNNE, J. (1975) Physiology of the natural polyamines putrescine, spermidine and spermine. Med. Biol. 53 : $121-147$.

Rheinwald, J. G. and Green, H. (1977) Epidermal growth factor and the multiplication of cultured human epidermal keratinocytes. Nature 265: 421-424.

RICE, R. and GREEN, H. (1978) Relation of protein synthesis and transglutaminase activity to formation of the cross-linked envelope during terminal differentiation of the cultured human epidermal keratinocyte. $J$. Cell Biol. 76: 705-711.

Roseeuw, D. I., Marcelo, C. L., Duell, E. A. and Voorhees, J. J. (1979) Cyclic AMP stimulates epidermal cell ornithine decarboxylase activity and epidermal cell proliferation. J. invest. Derm. 72: 272.

Rusin, L. J., Duell, E. A. and Voorhees, J. J. (1978) Papverine and Ro 20-1724 inhibit cyclic nucleotide phosphodiesterase activity and increase cyclic AMP levels in psoriatic epidermis in vitro. J. invest Derm. 71: $154-156$.

Russell, D. H. (1973) Polyamines in Normal and Neoplastic Growth. Proceedings of a Symposium of the National Cancer Institute, U.S.A. Raven Press, New York.

Russell, D. H. and Durie, B. G. (1978) Polyamines as Biochemical Markers of Normal and Malignant Growth. Progress in Cancer Research and Therapy, Vol. 8. Raven Press, New York.

Russell, D. H., Combest, W. L., Duell, E. A., Stawiski, M. A., Anderson, T. F. and Voorhees, J. J. (1978) Glucocorticoid inhibits elevated polyamine biosynthesis in psoriasis. $J$. invest. Derm. 71: 177-181.

SAMUELSSON, B. (1976) Introduction: new trends in prostaglandin research. In Advances in Prostaglandin and Thromboxane Research, Vol. 1, pp. 1-6, SAmuelsson, B. and PaOletri, R. (eds). Raven Press, New York.

Samuelsson, B. and PaOlettI, R. (1976) Advances in Prostaglandin and Thromboxane Research, Vol. 1. Raven Press, New York.

Simon, P., Pennys, N., LoRd, Je, Ziboh, V. A. and Mandy, S. (1977) A human model system for the release of endogenous inhibitor(s) of prostaglandin biosynthesis. Prostaglandins 14: 363-369.

Søndergaard, J., Helin, P. and Jørgensen, H. (1973) Human cutaneous inflammation induced by prostaglandin $\mathrm{E}_{1}$. J. Pathol. 109: 239-243.

Stawiski, M. A., Powell, J. A., Lang, P., Schork, A., Duell, E. A. and Voorhees, J. J. (1975) Papaverine: its effects on cyclic AMP in vitro and psoriasis in vivo. J. invest. Derm. 64: 124-127.

Steiner, A. L., Kipnis, D. M. and PARKer, C. (1969) Radioimmunoassay for the measurement of adenosine 3',5'-cyclic phosphate. Proc. natn Acad. Sci. U.S.A. 64: 367-373.

SUN, T. and GREEN, H. (1976) Differentiation of epidermal keratinocyte in cell culture: formation of the cornified envelope. Cell 9: 511-521.

TABOR, C. W. and TABOR, H. (1976) 1,4-Diaminobutane (putrescine), spermidine, and spermine. A. rev. Biochem. 45: $285-306$

TEGNER, E. (1976). Reversible overcurvature of the nailes after treatment with practolol. Acta derm.-vener., Stockh. 56: 493-495.

Tsambaos, D., Kalofoutis, A., Stratigos, J., Miras, C. and Capetanakis, J. (1977) Thin-layer chromatography of phospholipid components of normal psoriatic epidermis. Br. J. Derm. 97: 135-138.

Verma, A. K., Dixon, K., Froscio, M. and Murray, A. (1976) Localization of adenosine 3',5'-monophosphate in mouse epidermis by immunoflorescence. $J$. invest. Derm. 66: 239-241.

Verma, A. K., RICE, H. and Boutwell, R. K. (1977) Prostaglandins and skin tumor promotion: inhibition of tumor promoter-induced ornithine decarboxylase activity in epidermis by inhibitors of prostaglandin synthesis. Biochem. biophys. Res. Commun. 79: 1160-1166.

Voorhees, J. J., Duell, E. A., Stawiski, M. and Harrell, R. (1974) Cyclic nucleotide metabolism in normal and proliferating epidermis. In Advances in Cyclic Nucleotide Research, Vol. 4, pp. 117-162, GrEENGARD, P. and Robison, G. A. (eds). Raven Press, New York.

Voorhees, J. J., Kelsey, W., Stawiski, M., Smith, E., Duell, E. A., Haddox, M. and Goldberg, N. (1973) Increased cyclic GMP and decreased cyclic AMP levels in the rapidly proliferating epithelium of psoriasis. In The Role of Cyclic Nucleotides in Carcinogenesis, Vol. 6, pp. 325-373, SchulTz, J. GratzNER, H. G. (eds). Proceedings from the Miami Winter Symposia. Academic Press, New York.

Voorhees, J. J., Duell, E. A., Bass, L. J., Powell, J. A. and Harrell, E. R. (1972a). The cyclic AMP system in normal and psoriatic epidermis. J. invest. Derm. 59: 114-120.

Voorhees, J. J., Duell, E. A., Bass, L. J., Powell, J. A. and Harrell, E. R. (1972b) Decreased cyclic AMP in the epidermis of lesions of psoriasis. Archs Derm. 105: 695-701.

Voorhees, J. J., Duell, E. A. and Kelsey, W. H. (1972c) Dibutyryl cyclic AMP inhibition of epidermal cell division. Archs Derm. 105: 384-386.

Voorhees, J. J., Chakrabarti, S. B. and Bernstein, I. A. (1968) The metabolism of "histidine-rich" protein in normal and psoriatic keratinization. J. invest. Derm. 51 : 344-354.

WADSKov, S. and SøNDERGAARD, J. (1978) Determination of cyclic AMP in heat-separated human epidermal tissue. Acta derm.-vener., Stockh. 58: 191-195.

Watson, W., CanN, H. M., Farber, E. and Hall, M. L. (1971) The genetics of psoriasis. Archs Derm. 105: 197-207.

Weinstein, G. D. and McCullough, J. L. (1973) Cytokinetics in diseases of epidermal hyperplasia. A. Rev. Med. 24: $345-352$.

White, A. A., Crawford, K. M., Patt, C. S. and Lad, P. J. (1976) Activation of soluble guanylate cyclase from rat lung by incubation or by hydrogen peroxide. J. biol. Chem. 51 : 7304-7312.

WiLEY, H. and WeINSTEIN, G. (1977) Selective proliferative abnormally induced by propanolol in uninvolved psoriatic skin compared to normal skin. J. invest. Derm. 68: 239. 
WILKInson, D. I. and WALSH, J. T. (1977) Prostaglandin biosynthesis in the epidermis and dermis of young mouse skin and the effects of calcium and cyclic nucleotides. $J$. invest. Derm. 68: 210-214.

Woodrow, J. C., Dave, V. K., Usher, N. and Anderson, J. (1975) The HL-A system and psoriasis. Br. J. Derm. 92: 427-436.

Yoshikawa, K., Adachi, K., Halprin, K. M. and Levine, V. (1975a) Is the cyclic AMP in psoriatic epidermis low? Br. J. Derm. 93: 253-258.

Yoshikawa, K., Adachi, K., Halprin, K. M. and Levine, V. (1975b) The effects of catecholamine and related compounds on the adenyl cyclase system in the epidermis. Br. J. Derm. 93: 29-36.

ZIBOH, V. A. (1973) Biosynthesis of prostaglandin $E_{2}$ in human skin: subcellular localization and inhibition by unsaturated fatty acids and anti-inflammatory drugs. J. Lipid Res. 14: 377-384.

ZiboH, V. A. and BLANK, H. (1973) Die rolle der prostaglandine in der haut. Der Hautarzt. 24: 519-522. 